\title{
Correlation of methicillin resistance and virulence genes of Staphylococcus aureus with infection types and mode of acquisition in Sofia, Bulgaria
}

\author{
${ }^{1 *}$ Gergova, R. T., ${ }^{1}$ Tsitou, V. S., ${ }^{2}$ Gergova, I. I., ${ }^{1}$ Muhtarova, A. A., and ${ }^{1}$ Mitov, I. G. \\ ${ }^{1}$ Department of Medical Microbiology, Faculty of Medicine, \\ Medical University of Sofia, 2 Zdrave str., 1431-Sofia, Bulgaria \\ ${ }^{2}$ Department of Military Epidemiology and Hygiene, Military Medical Academy, Sofia, Bulgaria \\ *Correspondence to: rtgergova@gmail.com; +35929172547
}

\begin{abstract}
:
Background: Infections due to methicillin resistant Staphylococcus aureus (MRSA) which is the most virulent species among the staphylococci have become a global health challenge. The aim of this study was to assess the correlation of genes encoding virulence and methicillin resistance in invasive and non-invasive isolates from inpatients/outpatients with staphylococcal infections in Sofia, Bulgaria.

Materials and methods: Non-duplicate $S$. aureus isolates were recovered from clinical samples obtained from a total of 368 in-patients with healthcare-associated infections and outpatients with community acquired infections, following overnight cultures of samples on Columbia agar with $5 \%$ sheep blood at $35^{\circ} \mathrm{C}$. The isolates were presumptively identified by colony and Gram stain morphology, positive catalase reaction and plasma-coagulase test. Isolates were screened for methicillin resistance by the cefoxitin disk method according to the European Committee on Antimicrobial Susceptibility Testing (EUCAST) protocol. The mecA and mecC, and 12 staphylococcal virulence genes were detected by a combination of monoplex and multiplex polymerase chain reaction (PCR) assays.

Results: The prevalence of MRSA based on carriage of mecA gene was $12 \% ; 7.7 \%$ for outpatients and $16.2 \%$ for inpatients $(p<0.05)$. The frequency of toxin genes detection in the staphylococcal isolates were as follows; sei $(72.6 \%)$, seb $(59.8 \%)$, seh $(41.3 \%)$, sec $(38.3 \%)$, seg $(37.5 \%)$, sej $(32.3 \%)$, sea $(26.6 \%)$, sed $(10.3 \%)$, tst $(6.5 \%)$, and see $(4.3 \%)$. The virulence genes, tst, sea, seb, sec, seg, seh and sei were more frequently associated with MRSA than methicillin sensitive (MSSA) strains $(p<0.05)$. About one-third of the clinical $S$. aureus isolates harbored seven virulence genes; sea, seb, sec, see, seg, seh and sei, that were detected significantly more among the invasive isolates $(p<0.05)$.

Conclusions: This study shows the occurrence of highly virulent staphylococcal isolates in our geographical region.
\end{abstract}

Key words: Staphylococcus aureus, virulence, methicillin resistance

Received May 17, 2019; Revised June 5, 2019; Accepted June 7, 2019

Copyright 2019 AJCEM Open Access. This article is licensed and distributed under the terms of the Creative Commons Attrition 4.0 International License (http://creativecommmons.org/licenses/by/4.0), which permits unrestricted use, distribution and reproduction in any medium, provided credit is given to the original author(s) and the source.

\section{Corrélation des gènes de résistance à la méthicilline et de virulence de Staphylococcus aureus avec les types d'infection et le mode d'acquisition à Sofia, Bulgarie}

\author{
${ }^{1 *}$ Gergova, R. T., ${ }^{1}$ Tsitou, V. S., ${ }^{2}$ Gergova, I. I., ${ }^{1}$ Muhtarova, A. A., et ${ }^{1}$ Mitov, I. G. \\ ${ }^{1}$ Département de microbiologie médicale, Faculté de médecine, \\ Université médicale de Sofia, 2, Zdrave str., 1431-Sofia, Bulgarie \\ ${ }^{2}$ Département d'épidémiologie et d'hygiène militaires, Académie de médecine militaire, \\ Sofia, Bulgarie \\ *Correspondence à: rtgergova@gmail.com; +35929172547
}

\section{Abstrait:}

Contexte: Les infections dues à Staphylococcus aureus résistant à la méthicilline (SARM) l'espèce la plus virulente parmi les staphylocoques, sont devenues un problème de santé mondial. Le but de cette étude était 
d'évaluer la corrélation des gènes qui codant pour la virulence et la résistance à la méthicilline avec des isolats invasifs ou non invasifs de patients hospitalisés/ambulatoires patients infectés par le staphylocoque dans Sofia, Bulgarie.

Matériels et méthodes: Des isolats de $S$. aureus non dupliqués ont été récupérés à partir d'échantillons cliniques prélevés chez 368 patients atteints d'infections associées aux soins de santé et de patients ambulatoires présentant des infections acquises en communauté, après avoir effectué des cultures pendant la nuit d'échantillons sur de la gélose Columbia contenant $5 \%$ de sang de mouton à $35^{\circ} \mathrm{C}$. Les isolats ont été présumés identifiés par la morphologie de la colonie et de la coloration de Gram, la réaction positive à la catalase et le test plasma-coagulase. Les isolats ont été criblés pour la résistance à la méthicilline par la méthode de la céfoxitine selon le protocole du Comité européen sur les tests de sensibilité aux antimicrobiens (EUCAST). Les gènes mecA et $m e c C$, ainsi que 12 gènes de virulence staphylococcique ont été détectés par une combinaison de tests de réaction en chaîne de la polymérase (PCR) monoplex et multiplex.

Résultats: La prévalence de SARM basée sur le portage du gène mecA était de $12 \% ; 7,7 \%$ pour les patients ambulatoires et $16,2 \%$ pour les patients hospitalisés $(p<0,05)$. La fréquence de détection des gènes de toxines dans les isolats de staphylocoques était la suivante: sei $(72,6 \%)$, seb $(59,8 \%)$, seh $(41,3 \%)$, sec $(38,3 \%)$, seg $(37,5 \%)$, sej $(32,3 \%)$, sea $(26,6 \%)$, sed $(10,3 \%)$, tst $(6,5 \%)$ et see $(4,3 \%)$. Les gènes de virulence, tst, sea, seb, sec, seg, seh et sei étaient plus fréquemment associés à SARM que les souches sensibles à la méthicilline (MSSA) $(p<0,05)$. Environ un tiers des isolats cliniques de $S$. aureus portaient sept gènes de virulence; sea, seb, sec, see, seg, seh et sei, qui ont été détectés significativement plus parmi les isolats invasifs $(p<0,05)$.

Conclusion: Cela crée un risque de propagation d'isolats très virulents dans la région géographique

Mots-clés: Staphylococcus aureus, virulence, résistance à la méthicilline

\section{Introduction:}

Staphylococcus aureus is a facultative anaerobic gram-positive coccus, with grapelike arrangement. This bacterial specie is a clinically relevant human and animal pathogen. In humans, $S$. aureus is a major cause of both community acquired (CA) and nosocomial or healthcare-associated (HA) infections such as skin, soft tissue and bone infections, postoperative wound infections, upper respiratory tract infections, pneumonia, bacteraemia and endocarditis (1-5). S. aureus is also among the most common pathogens causing food-borne diseases (6-10) and is associated with suppurative diseases in animals such as mastitis, septic arthritis, endocarditis, osteomyelitis, urinary tract infections and sepsis $(7,11,12)$.

In many cases of staphylococcal infections, the clinical manifestations are associated with production of toxins, of which the most notable ones are toxic shock syndrome toxin 1 (TSST-1), heat-stable pyrogenic enterotoxins (SEs) responsible for food poisoning with 20 serologically distinct types, and epidermolytic (exfoliative) toxins (ET) responsible for scalded skin syndrome (SSS), occurring in many forms as ETA, ATB and ATD $(6,13-16)$. The most severe invasive and fatal infections caused by $S$. aureus are due to the cumulative effects of various extracellular products such as enzymes (thermonuclease, hyaluronidase, lipase), haemolysins/cytolysins, and other toxins, especially those exhibiting super-antigen activity $(3,6,13)$.

The super-antigens (SAgs), TSST-1 and SEs, which stimulate polyclonal proliferation of $\mathrm{T}$ lymphocytes and noneffective immune responses are the most important toxigenic determinants and virulence mediators in $S$. aureus infections (6, $10,17,18)$.

Methicillin resistant $S$. aureus (MRSA) can form a strong biofilm and easily colonize mucosa, endovascular catheters and/or implants, which is one reason why it causes chronic, recurrent or invasive nosocomial infections $(4,19,20)$. This aim of this study is to assess the correlation between methicillin resistance, and virulence genes encoding predominantly SAgs, with invasive or noninvasive and $\mathrm{CA}$ or $\mathrm{HA}$ types of infection due to $S$. aureus.

\section{Materials and methods:}

\section{Study setting and isolation of $\boldsymbol{S}$. aureus}

This study was conducted in three University Hospitals in Sofia, Bulgaria during the period September 2016 and November 2018. A total of 368 non-duplicate $S$. aureus were isolated from various human clinical samples obtained from in-patients with HA infections (185 isolates) and outpatients with CA infections (183 isolates), after overnight cultures of clinical samples on Columbia agar with $5 \%$ sheep blood (Himedia, India) at $35^{\circ} \mathrm{C}$ in aerobic atmosphere.

S. aureus was presumptively identified by colony and Gram stain morphology, positive catalase reaction and plasmacoagulase test (Rabbit Plasma, Himedia, India). Detailed biochemical identification, where necessary, was done with Crystal GP (Beckton Dickinson, Germany). Isolates were screened for methicillin resistance by the cefoxitin disk method according to the European Committee on Antimicrobial Susceptibility Testing (EUCAST) guidelines (http://www.eucast.org) (21). The isolates were stored in skim milk at $-70^{\circ} \mathrm{C}$ until use. 
Prior to the commencement of genotypic characterization, the isolates were sub-cultured three times on Brain Heart Infusion (BHI) agar (Himedia, India).

\section{DNA extraction}

Genomic DNA of pure cultures of isolates and control strains grown overnight on $\mathrm{BHI}$ agar (Himedia, India) at $35^{\circ} \mathrm{C}$ in $\mathrm{O}_{2}$ containing atmosphere, were extracted using a DNAsorb-AM nucleic acid extraction kit (AmpliSens) in accordance with the manufacturer's instructions.

\section{Polymerase chain reaction (PCR) assay}

All phenotypically identified $S$. aureus strains were confirmed by PCR assay using species-specific primers targeting Sau 327 and Sau 164523 S rRNA genes $(8,12)$. All confirmed $S$. aureus strains were then screened for carriage of mecA and mecC genes which encode abnormal penicillin binding proteins of the staphylococcal cell wall of MRSA, and for 12 virulence genes using primers as shown in Table 1 . The primer sequences were verified for specificity using the Basic Local Alignment Search Tool (BLAST) program available at the NCBI website, Bethesda, Maryland, USA (http//:www.nbi.nlm.nih.gov/BLAST).

PCR was performed in a $25 \mu \mathrm{l}$ reaction mix. DNA was amplified after optimization of the reaction using the following protocol; initial denaturation at $95^{\circ} \mathrm{C}$ for 3 minutes followed by denaturation at $95^{\circ} \mathrm{C}$ for $35 \mathrm{~s}$; annealing at $54-63^{\circ} \mathrm{C}$ depending on primers (Table 1 ), extension at $72^{\circ} \mathrm{C}$ for 1 minute $30 \mathrm{~s}$; and final extension at $72^{\circ} \mathrm{C}$ for 7 minutes. Prior to multiplex PCR assay, each gene was individually amplified (monoplex PCR). After successful reaction and visualization of amplicons in the monoplex PCR, mixes with two or more pairs of primers were prepared and amplifications were repeated by multiplex PCR.

Four sets of multiplex PCR were used to detect the genes of interest with the following mixes; Mix I contain primers for $\mathrm{hlg}$, sea, sed and tst genes; Mix II contains primers, Sau 327 and Sau 1645 for specific $S$. aureus 235 rRNA gene, and primers for enterotoxin seg; Mix III contains primers for seh, see and sej genes; and Mix IV contains primers for cna, seb, sec, and sei genes. Monoplex PCR was used for Mix V and Mix VI which contains primers for mecA and mecC respectively, according to the criteria and protocols $(4,22)$ presented in Table 1.

S. aureus ATCC 29213 was used as a negative control strain for methicillin resistance (MSSA), and $S$. aureus ATCC 43300 and ATCC BAA2312 were used as positive control strains (MRSA) for mecA and mecC respectively. The amplified genes were separated on $1.5 \%$ agarose gel for $25-35$ minutes at $140 \mathrm{~V}$, stained with ethidium bromide $(0.5 \mu \mathrm{g} / \mathrm{mL})$ and visualized by UV trans-illumination (wavelength $312 \mathrm{~nm}$ ). The PCR products were identified on the basis of their expected fragment size as presented in Table 1.

Table 1: The primers sequences and amplification conditions for detection of virulence genes of Bulgarian human isolates of Staphylococcus aureus

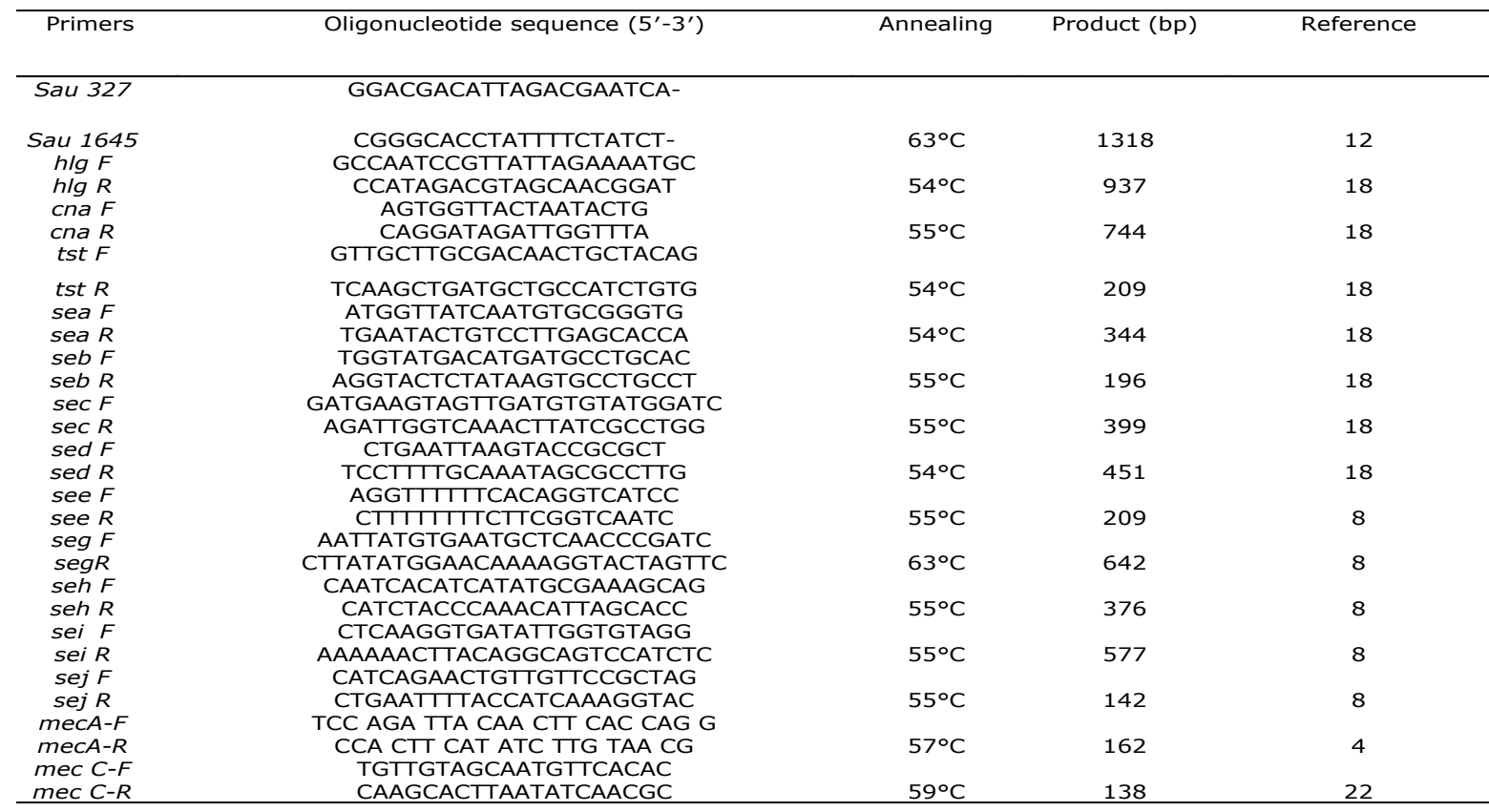




\section{Statistical analysis}

All statistical analyses were performed using SPSS 19.0 software (SPSS Inc., Chicago, IL, United States). Results were considered statistically significant at $p<0.05$.

\section{Results:}

Of the 368 Bulgarian S. aureus isolates, $168(45.7 \%)$ invasive isolates were obtained from sterile body sites; 34 from blood cultures, 88 from abscesses or soft tissue infections, 14 from middle ear fluids, 13 from sinus punctures, 12 from tracheal aspirates, 4 from joint aspirates, and 3 from bones in cases with osteomyelitis. Two hundred $(54.3 \%)$ non-invasive isolates were recovered from 109 nasal/nasopharyngeal secretions, 58 from skin lesions (impetigo, furunculosis), 24 from uro-genital tract, and 9 from eye secretions (Table 2).

A total of 44 out of the 368 S. aureus were methicillin resistant, giving a MRSA prevalence rate of $12 \%$. All the phenotypic MRSA strains were positive for mecA gene but none contained mecC gene. Only $7.7 \%$ (14 of 368) MRSA were isolated from outpatients, which was significantly less $(p<$ $0.05)$ compared to those from inpatients (16.2\%, 30 of 368) (Table 3). The distribution of virulence genes in both MRSA and MSSA isolates as well as among inpatients with $\mathrm{HA}$ infection, and outpatients with CA infections, is presented in Table 3.

The most prevalent virulence gene in all the groups was $h / g$, which encodes a poreforming gamma-toxin with a wide-spectrum cytolytic effect and found in approximately $100 \%$ of the isolates. There was no significant difference in the frequency of $\mathrm{h} / \mathrm{g}$ gene among patients with $C A$ and $H A$ infections (Table 3), and among invasive and non-invasive infections (Tables 4 ), but it was dominant in MSSA isolates $(p<0.05)$ (Table $3)$. The virulence genes; tst, sea, seb, sec, seg, seh and sei (except hlg) were detected more frequently in MRSA than MSSA isolates $(p<0.05)$ (Table 3$)$. Only two genes, seb and $s e c$, were predominantly observed in relation to staphylococcal inpatient infections $(p<0.05)$.

MRSA strains were dominant (with $63.6 \%$ ) among the invasive isolates compared to $36.4 \%$ among the non-invasive ones $(p<0.05)$ (Table 4$)$. The SAgs encoding genes; sea, seb, sec, see, seg, seh, and sei were detected more frequently among the invasive isolates $(p<0.05)$ (Table 4). In addition, the cna gene, encoding a bacterial collagen adhesin with an inhibitory effect on complement activation, was detected in $14.2 \%$ of the $S$. aureus isolates, predominantly among in-patients and in invasive infections $(p<0.05)$.

The distribution of the staphylococcal toxin genes detected in this study compared with data from other countries is shown in Table 5. The frequency of virulence genes detected in this study are; sei $(72.6 \%)$, seg $(67.5 \%)$, seb $(60.3 \%)$, seh $(41.3 \%)$, sec $(38.3 \%)$, sej $(32.3 \%)$, sea $(26.6 \%)$, sed $(10.3 \%)$, tst $(6.5 \%)$, and see $(4.3 \%)$. Fig 1 shows the gel electrophoresis picture of the amplified products of $S$. aureus mec and virulence genes in the 4 multiplex PCR reactions (Mixes I-IV) and the two monoplex $\mathrm{PCR}$ reactions (Mixes $\mathrm{V}$ and $\mathrm{VI}$ ).

Table 2: Distribution of Staphylococcus aureus isolates by clinical specimen types

\begin{tabular}{cc}
\hline Specimen types/isolates & No of isolates (\%) \\
\hline Invasive isolates & $168(45.7)$ \\
Blood culture & $34(9.2)$ \\
Abscess/Soft tissue & $88(23.9)$ \\
Middle ear fluid & $14(3.8)$ \\
Sinus punctures & $13(3.5)$ \\
Trachea aspirates & $12(3.3)$ \\
Joint aspirates & $4(1.1)$ \\
Bone samples & $3(0.8)$ \\
Non-invasive isolates & $200(54.3)$ \\
Nasopharyngeal secretion & $109(29.6)$ \\
Skin lesion & $58(15.8)$ \\
Urogenital tract & $24(6.5)$ \\
Eye secretion & $9(2.4)$ \\
& Total
\end{tabular}


Table 3: The frequency of virulence genes among MRSA and MSSA isol ates from inpatients and outpatients

\begin{tabular}{|c|c|c|c|c|c|c|c|c|c|c|c|}
\hline \multirow[t]{2}{*}{ Genes } & \multicolumn{3}{|c|}{$\begin{array}{l}\text { MRSA } \\
(n=44)\end{array}$} & \multicolumn{3}{|c|}{$\begin{array}{c}\text { MSSA } \\
(n=324)\end{array}$} & & \multicolumn{4}{|c|}{$\begin{array}{c}\text { Total number of } S \text {, aureus isolates } \\
\qquad(n=368)\end{array}$} \\
\hline & $\begin{array}{c}\text { Inpatient } \\
\% \\
(n=30)\end{array}$ & $\begin{array}{c}\text { Outpatient } \\
\% \\
(n=14)\end{array}$ & $\begin{array}{r}\text { Total } \\
(\%)\end{array}$ & $\begin{array}{c}\text { Inpatient } \\
(\%) \\
(n=155)\end{array}$ & $\begin{array}{c}\text { Outpatient } \\
\% \\
(n=169)\end{array}$ & $\begin{array}{l}\text { Total } \\
(\%)\end{array}$ & $\begin{array}{c}\text { p value } \\
\text { (between } \\
\text { MRSA and } \\
\text { MSSA) }\end{array}$ & $\begin{array}{c}\text { Inpatient } \\
\% \\
(n=183)\end{array}$ & $\begin{array}{c}\text { Out- } \\
\text { patient } \\
(\%) \\
(n=185)\end{array}$ & $\begin{array}{l}\text { p value } \\
\text { (between } \\
\text { Inpatient } \\
\text { and Out- } \\
\text { patient) }\end{array}$ & $\begin{array}{l}\text { Total } \\
(\%)\end{array}$ \\
\hline$h i g$ & 93.3 & 100 & 88.6 & 98.1 & 98.8 & 98.5 & $0.0031^{*}$ & 95.7 & 98.9 & 0.1046 & 97,3 \\
\hline na & 33.3 & 0 & 22.7 & 23.2 & 3.6 & 13.0 & 0.1035 & 24.8 & 3.2 & 0.0001 & 14.2 \\
\hline tst & 20.0 & 28.6 & 22.7 & 4.5 & 4.1 & 4.3 & 0.0001 & 7.0 & 6.0 & 0.8334 & 6.5 \\
\hline sea & 53.3 & 85.7 & 63.6 & 23.9 & 19.5 & 21,6 & 0.0001 & 28.6 & 24.6 & 0.1257 & 26.6 \\
\hline seb & 86.7 & 100 & 90.9 & $66.5)$ & 46.7 & 56.2 & 0.0001 & 69.7 & 50.8 & 0.0003 & 60.3 \\
\hline sec & 66.6 & 57.1 & 63.6 & 49.7 & 21.3 & 34.9 & 0.0004 & 52.4 & 29.5 & 0.0004 & 38.3 \\
\hline sed & 10.0 & 7.1 & 9.1 & 12.3 & 8.3 & 10.5 & 1.0000 & 12.4 & 8.2 & 0.2304 & 10.3 \\
\hline see & 0 & 0 & 0 & 7.7 & $2 A$ & 4.9 & 0.2350 & 6.5 & 2.2 & 0.0706 & 4.3 \\
\hline seg & 86.7 & 100 & 90.9 & 66.5 & 69.8 & 64.2 & 0.0002 & 69.7 & 65.0 & 0.3741 & 67.4 \\
\hline she & 53.3 & 85.7 & 63.6 & 43.2 & 33.7 & 38.3 & 0.0018 & 44.9 & 37.7 & 0.1703 & 41.3 \\
\hline sei & 90.0 & 100 & 93.2 & 69.7 & 69.8 & 69.8 & 0.0005 & 73.0 & 72.1 & 0.9072 & 72.6 \\
\hline sej & 33.3 & 50.0 & 38.6 & 34.2 & 29.0 & 31.5 & 0.3908 & 34,0 & 30.6 & 0.5049 & 32,3 \\
\hline
\end{tabular}

*Results were considered statistically significant at $p<0.05$ - in dark field

Table 4: The frequency of virulence genes among MRSA and MSSA inv asive and noninvasive isolates

\begin{tabular}{|c|c|c|c|c|c|c|c|c|c|c|}
\hline \multirow[t]{2}{*}{ Genes } & \multicolumn{3}{|c|}{$\begin{array}{c}\text { MRSA } \\
(n=44)\end{array}$} & \multicolumn{3}{|c|}{$\begin{array}{c}\text { MSSA } \\
(n=324)\end{array}$} & \multicolumn{4}{|c|}{$\begin{array}{l}\text { Total number of } S \text {. aureus isolates } \\
\qquad(n=368)\end{array}$} \\
\hline & $\begin{array}{c}\text { Invasive } \\
\text { isolates } \\
\% \\
(n=28)\end{array}$ & $\begin{array}{c}\text { Non- } \\
\text { invasive } \\
\text { isolates } \\
\% \\
(n=16)\end{array}$ & $\begin{array}{c}\text { Total } \\
(\%)\end{array}$ & $\begin{array}{c}\text { Invasive } \\
\text { isolates } \\
(\%) \\
(n=140)\end{array}$ & $\begin{array}{c}\text { Non- } \\
\text { invasive } \\
\text { isolates } \\
\% \\
(n=184)\end{array}$ & $\begin{array}{c}\text { Total } \\
(\%)\end{array}$ & $\begin{array}{c}\text { Invasive } \\
\text { isolates } \\
\% \\
(n=168)\end{array}$ & $\begin{array}{c}\text { Non- } \\
\text { invasive } \\
\text { isolates } \\
\% \\
(n=200)\end{array}$ & $\begin{array}{l}\text { p value } \\
\text { (between } \\
\text { invasive } \\
\text { and non- } \\
\text { invasive) }\end{array}$ & $\begin{array}{c}\text { Total } \\
(\%)\end{array}$ \\
\hline$h i g$ & 92.9 & 81.25 & $88.6)$ & 100.0 & 78.3 & 98.5 & 98.8 & 96.0 & 0.1179 & 97.3 \\
\hline $\begin{array}{l}c n a \\
\text { tst }\end{array}$ & $\begin{array}{l}35.7 \\
28.6\end{array}$ & $\begin{array}{c}0 \\
12.5\end{array}$ & $\begin{array}{l}22.7 \\
22.7\end{array}$ & $\begin{array}{r}25.7 \\
5.7\end{array}$ & $\begin{array}{l}3.3 \\
3.3\end{array}$ & $\begin{array}{c}13.0 \\
4.3\end{array}$ & $\begin{array}{c}24.8 \\
9.5\end{array}$ & $\begin{array}{l}3.0 \\
4.0\end{array}$ & $\begin{array}{c}0.0001 * \\
0.0358\end{array}$ & $\begin{array}{l}14.1 \\
6.5\end{array}$ \\
\hline sea & 60.7 & 68.75 & 63.6 & 24.3 & 19.6 & 21.6 & 30.4 & 23.5 & 0.1159 & 26.6 \\
\hline seb & 96.4 & 81.25 & 90.9 & 72.1 & 44.0 & 56.2 & 76.2 & 47,0 & 0.0001 & 60.3 \\
\hline sec & 71.4 & 50.0 & 63.6 & 48.6 & 24.5 & 34.9 & 52.4 & 26.5 & 0.0001 & 38.3 \\
\hline sed & 7.1 & 12.5 & 9.1 & 16.4 & 6.0 & 10.5 & 14.9 & 6.5 & 0.0098 & 10.3 \\
\hline see & 0 & 0 & 0 & 8.6 & 2.2 & 4.9 & 7.1 & 2.0 & 0.0201 & 4.3 \\
\hline seg & 85.7 & 100.0 & 90.9 & 77.9 & 53.8 & 64.2 & 79.2 & 57.5 & 0.0001 & 67.4 \\
\hline seh & 57.1 & 85.0 & 63.6 & 43.2 & 31.0 & 38.3 & 49.4 & 34.5 & 0.0042 & 41.3 \\
\hline sei & 100.0 & 81.25 & 93.2 & 47.9 & 64.1 & 69.8 & 81.0 & 65.5 & 0.0010 & 72.6 \\
\hline sej & 34.1 & 50.0 & 38.6 & 37.9 & 26.6 & 31.5 & 36.9 & 59.5 & 0.0940 & 32.3 \\
\hline
\end{tabular}

*Results were considered statistically significant at $p<0,05$ - in dark field 
Table 5: Distribution of staphylococcal virulence genes (SAgs) among S. aureus isolates from Bulgaria and other countries

\begin{tabular}{|c|c|c|c|c|c|c|c|c|c|c|}
\hline $\begin{array}{c}\text { Virulence } \\
\text { genes } \\
\text { (SAgs) }\end{array}$ & $\begin{array}{c}\text { Bulgaria } \\
\text { (this study) } \\
\%\end{array}$ & $\begin{array}{c}\text { Turkey } \\
\%\end{array}$ & $\begin{array}{c}\text { Czech } \\
\text { Republic } \\
\%\end{array}$ & $\begin{array}{c}\text { France }^{32} \\
\%\end{array}$ & $\begin{array}{c}\text { Colombia } \\
\%\end{array}$ & $\begin{array}{c}\text { Canada } \\
\%\end{array}$ & $\begin{array}{c}\text { China }^{30} \\
\%\end{array}$ & $\begin{array}{c}\text { India } \\
\%\end{array}$ & $\begin{array}{c}\text { Kore } a^{33} \\
\%\end{array}$ & $\begin{array}{c}\operatorname{Iran}^{25,26} \\
\%\end{array}$ \\
\hline tst & 6.5 & 27.9 & 2 & $0-38$ & 6.2 & 24.3 & 48.1 & 24.3 & 52.6 & 25.0 \\
\hline sea & 26.6 & $4.6-13.5$ & 12 & $6-34$ & 11.1 & 19.6 & 44.4 & 38.6 & 47.4 & 40.6 \\
\hline seb & 59.8 & 8.7 & 3 & $0-31$ & 9.9 & 5.6 & 6.48 & 26.8 & 0 & 25.0 \\
\hline $\sec$ & 38.3 & $4.0-52.9$ & 2 & $0-19$ & 16.0 & 7.5 & 9.26 & 0 & & 0 \\
\hline sed & 10.3 & 4.8 & 17 & $0-14$ & 3.7 & 1.9 & 5.56 & 0 & 0 & 0 \\
\hline see & 4.3 & 0 & 0 & 0 & 3.2 & 0 & 0 & 0 & 0 & 0 \\
\hline $\operatorname{seg}$ & 67.4 & $24.6-89.4$ & 77 & 75 & 51.9 & & 40.7 & & 61.1 & 27.8 \\
\hline seh & 41.3 & 35.6 & 0 & $0-20$ & 35.8 & & 1.85 & & & \\
\hline sei & 72.6 & $51.3-65.4$ & 77 & 75 & 44.4 & & 14.8 & & 70.5 & \\
\hline sej & 32.3 & $0.66-22.1$ & 17 & & 3.7 & & 13.9 & & & \\
\hline
\end{tabular}
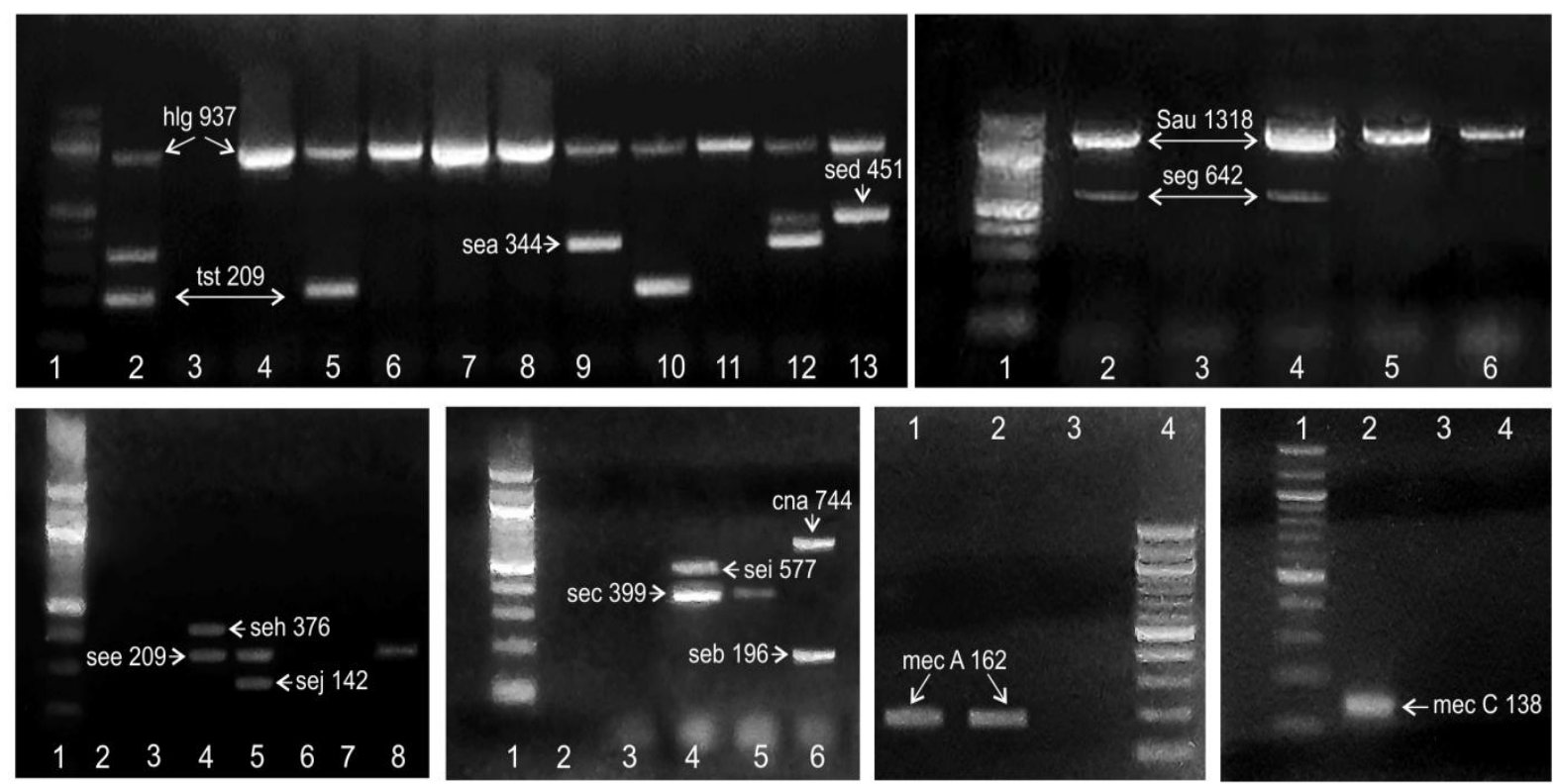

Fig 1: Gel electrophoresis of the PCR products of Staphylococcus aureus virulence and mec genes (Amplicons from mixes I, II, III, IV, V, VI)

\section{Discussion:}

There are wide differences in the reported geographical distribution of MRSA, from $2.9 \%$ to $8.7 \%$ in Turkish nasal carriers and respiratory tracts of ill persons $(3,23)$, up to $38.7 \%$ in Colombia $(16), 39.6 \%$ in India (24), 41-48\% in Iran $(25,26)$ and $44 \%$ in Nigeria from animal samples (27). The methicillin resistance rate observed in this study was $12 \%$, with $7.7 \%$ from outpatients and $16.2 \%$ from inpatients. The prevalence of MRSA is known to vary in relation to where the infection was acquired, whether in the community (CA) or in healthcare (HA) setting $(3,4,5,19,20)$.

In almost all the $S$. aureus isolates in our study, we found the h/g gene in the genome of the organism in both MSSA and MRSA (though more frequent in MSSA), 
invasive and non-invasive, and $\mathrm{CA}$ and $\mathrm{HA}$ isolates. This gene is responsible for the synthesis of extracellular toxic polypeptide (gamma-haemolysin) with strong cytolytic activity against a broad spectrum of eukaryotic cells (erythrocytes, neutrophils, monocytes, lymphocytes, macrophages) and non-specific activity against intracellular membrane structures in various mammalian cells with detergent-like action (28). Available data suggest that $h / g$ extracellular product contributes to immune evasion and potential staphylococcal survival in biological fluids. In high concentration, this bi-component poreforming toxin has dermo-necrotic and lethal activity in experimental animal model and is being studied as a potential component of a multivalent vaccine (28). Our results are similar to data from the USA and Iran reporting high prevalence of $h / g$ among MRSA and MSSA isolates $(25,29)$.

In contrast, the cna gene was detected in only about $14 \%$ of the staphylococcal isolates. $S$. aureus can produce collagen adhesin (CNA) to interact with collagen in humans and animals. This adhesin plays a leading role in colonization, prolongation and persistence of $S$. aureus infection in human host. Another mechanism of CNA action is inhibition of complement activation. In experimental animal models, progression of bacterial infections as a result of staphylococcal CNA or other adhesins such as YadA of Yersinia enterocolitica, Enterococcus faecalis adhesin ACE, E. faecium adhesin ACM, and Streptococcus mutans adhesin CNM, have been established (30). The frequent correlation of cna with invasive isolates predominantly in inpatients suggests cna encodes a product with high and specific virulent potential.

The combinations of three genes, sei, seg and seb, which codes for strong superantigens (SAgs) were detected in more than $60 \%$ of the Bulgarian staphylococcal isolates tested in this study, predominantly among invasive isolates. About one-third of the clinical $S$. aureus isolates harbored seven genes, sei, seb, seh, sec, seg, sej, and sea, encoding super-antigenic toxins, and as many as $25 \%$ of the isolates carried at least nine genes while nearly $40 \%$ carried at least six virulence genes. This high carriage rate put the populace at risk of infections from highly virulent $S$. aureus strains in our geographical region.

The frequency of SAgs gene detection reported varies from countries to countries as shown in Table 5 . The high prevalence of sei and seg genes in our study is similar to what has been reported in Turkish paediatric patients and healthy students $(3,23)$, and in Czech Republic, France, Colombia, Mexico and Korea $(16,20,31,32,33)$ but data from
India, China, Iran and Canada present sea as the most frequent SAgs gene $(24,25,34$, 35).

Among the MRSA isolates in our study, the genes encoding SEs that were dominant with high frequency $(63.6 \%$ to $93.2 \%)$ and significantly associated with methicillin resistance $(p<0.05)$ were sea, seb, sec, seg, seh and sei. This is similar to the study of Ortega at al., (5) who reported sea, seb, sed, seg, sei and sej genes as the most prevalent in their MRSA isolates. However, they detected tst-1 gene more frequently among their MSSA isolates, whereas in our study, tst-1 gene was more frequently detected in the MRSA isolates. The prevalence of tst-1 gene in the $S$. aureus isolates in the present study and from other European countries as shown in Table 5 is low compared to the prevalence in China and Korea (about $50 \%$ of isolates). The tst-1 gene was detected equally in isolates from inpatients and outpatients $(p>0.05)$ but was more frequently detected in the invasive staphylococcal isolates $(p<0.05)$. The prevalence of both seb and sec genes, which are the most frequently detected genetic elements in patients with $\mathrm{HA} S$. aureus infections and in invasive disease, was significantly higher $(p<0.05)$ in our study than from other countries.

The genetic profile of the invasive $S$. aureus isolates was different in the present study with more virulence genes detected compared to non-invasive isolates $(p<0.05)$. The genes mainly detected in the invasive staphylococcal isolates were cna, tst-1, seb, seh, sec, sed, see, seg, seh and sei in various combinations. Some of these genes have been reported to correlate with nosocomial and invasive infections $(16,20,24)$. In a Colombia study (16), five SAg genes out of 22 tested genetic elements were found in invasive isolates. Some of the genes, sei, sea and seg, most frequently detected in our study were reported to be harbored by more than $33 \%$ of $S$. aureus isolates in patients who died from staphylococcal bacteraemia (24).

\section{Conclusion:}

The prevalence of MRSA in the Bulgarian human staphylococcal isolates in our study was $12 \%$, and the strains were recovered mainly from patients with $\mathrm{HA}$ infections. More than $60 \%$ of the staphylococcal isolates carried sei, seg and seb genes which encode strong Sags predominantly among the invasive isolates, in addition to the $h / g$ gene which encode a poreforming toxin. Furthermore, approximately one-third of the clinical $S$. aureus isolates 
harbored seven (sei, seb, seh, sec, seg, sej and sea) out of the twelve virulence genes encoding super-antigen toxins, in addition to the $h / g$ gene. The results from the present study showed that the genome of clinical $S$. aureus isolates in Bulgaria contain wide array of genes encoding immuno-modulatory molecules. This may put the populace at risk of acquisition and spread of highly virulent $S$. aureus strains in our geographical region.

\section{Conflict of interest:}

\section{No conflict of interest is declared}

\section{References:}

1. Dafne, P-M., Viedma, E., Murcia, M., et al. Pathogenic characteristics of Staphylococcus aureus endovascular infection isolates from different clonal complexes. Front Microbiol. 2017; 8: 917.

2. Gergova, R., Petrova, G., Gergov, S., et al. Microbiological features of the upper respiratory tract infections in Bulgarian children for the period 19982014; our university's experience. Balk Med J. 2016; 33: $675-680$.

3. Karbuz, A., Karahan, Z. C., Aldemir-Kocabas, B., et al. Evaluation of antimicrobial susceptibilities and virulence factors of Staphylococcus aureus strains isolated from community-acquired and health-care associated pediatric infections. Turk J Pediatr. 2017; 59: 395-403. DOI:10.24953/turkjped.2017.04.005

4. Mehrshad, S., Haghkhah, M., and Aghaei, S. Epidemiology and molecular characteristics of methicillin-resistant Staphylococcus aureus from skin and soft tissue infections in Shiraz, Iran. Turk J Med Sci. 2016; 46: DOI:10.3906/sag-1507-164

5. Sipahi, O. R., Uysal, S., Aydemir, S. Ş., et al. Antibacterial resistance patterns and incidence of hospital-acquired Staphylococcus aureus bacteremia in a tertiary care educational hospital in Turkey: a perspective through 2001-2013. Turk J Med Sci. 2017; 47 (4): 1210 - 1215. DOI: $10.3906 / \mathrm{sag}-1607-$ 63

6. Ortega, E., Abrioue, H., Lucas, R., et al. Multiple Roles of Staphylococcus aureus Enterotoxins: Pathogenicity, Super-antigenic Activity, and Correlation to Antibiotic Resistance. Toxins. 2010; 2: 2117-2131; DOI:10.3390/toxins2082117

7. Momtaz, H., Dehkordi, F. S., Rahimi, E., et al. Virulence genes and antimicrobial resistance profiles of Staphylococcus aureus isolated from chicken meat in Isfahan province. Iran J Appl Poult Res. 2013; 22 (4): 913 - 921. https://doi.org/10.3382/japr.201200673

8. Özdemiri, H., and Keyvan, E. Isolation and characterization of Staphylococcus aureus strains isolated from beef, sheep and chicken meat. Ankara Üniv Vet Fak Derg. 2016; 63: 333-338

9. Jung, B. S., Lee, Y. J., Na-Kyoung, L., et al. Virulence Factors of Staphylococcus aureus Isolated from Korean Pork bulgogi: Enterotoxin Production and Antimicrobial Resistance. Korean J Food Sci An. 2015; 35: 502-506 DOI http://dx.doi.org/10.5851/ kosfa.2015.35.4.502

10. Argudín, M. Á., Mendoza, M. C., and Rodicio, M. R. Food Poisoning and Staphylococcus aureus Enterotoxins. Toxins. 2010; 2: 1751 - 1773. DOI: $10.3390 /$ toxins2071751

11. Li, T., Lu, H., Wang, X., et al. Molecular Characteristics of Staphylococcus aureus Causing Bovine Mastitis between 2014 and 2015. Front Cell Infect Microbiol. 2017; 7: 127. DOI: /fcimb.2017.00127

12. Cantekin, Z., Ergun, Y., Solmaz, H., et al. PCR assay with host specific internal control for Staphylococcus aureus from bovine milk samples. Mac Vet Rev.
2015; 38 (1): 97-100. DOI:10.14432/j.macvetrev. 2015.01.038

13. Kuroda, M., Nagasaki, S., Ito, R., et al. Sesquiterpene farnesol as a competitive inhibitor of lipase activity of Staphylococcus aureus. FEMS Microbiol Lett. 2007; 273: 28-34. DOI10.1111/j.1574-6968.2007.00772.x

14. Vancraeynest, D., Hermans, K., and Haesebrouck, F. Prevalence of genes encoding exfoliative toxins, leucotoxins and super antigens among high and low virulence rabbit Staphylococcus aureus strains. Vet Microbiol. 2007; 121: 368 - 372. https:// doi.org/10.1016/j.vetmic.2006.05.009

15. Kondo, Y., Ito, T., Ma, X. X., et al. Combination of Multiplex PCRs for Staphylococcal Cassette Chromosome mec Type Assignment: Rapid Identification System for $\mathrm{mec}, \mathrm{ccr}$, and Major Differences in Junkyard Regions. Antimicrob Agents Chemother. 2007; 51(1): 264-274. DOI:10.1128 /AAC.00165-06

16. Arias, L. F. C., Espinal, J. S. L., Ortiz, J. I. M., et al. Relationship between super antigenicity, antimicrobial resistance and origin of Staphylococcus aureus isolated. Colombia Médica. 2016; 47 (1): 15-20.

17. Marrack, P., and Kappler, J. The staphylococcal enterotoxins and their relatives. Science. 1990; 248:705

18. Reda, Z., Tarabees Zakaria, H., Hassanin Moustafa, A., et al. Molecular Screening of Some Virulence Factors Associated With Staphylococcus aureus Isolated From Some Meat Products. Alexandra J Vet Sci. 2016; 48 (1): 12-19. DOI: 10.5455/ajvs.184774

19. Parker, M G., and Doebbeling, B. N. The challenge of methicillin resistant Staphylococcus aureus prevention in hemodialysis therapy. Semin Dial. 2012; 25: 42-49. DOI: 10.1111/j.1525-139X.2011. 00999.x

20. Paniagua-Contreras, G. L., Vaca-Paniagua Felipe, E. M-P., Rodríquez-Moctezuma, J. R., et al. Expression of enterotoxin-coding genes in methicillin-resistant Staphylococcus aureus strains isolated from Mexican haemodialysis patients. Ann Clin Microbiol Anti. 2014; 13: 55 http://www.ann-clinmicrob.com /content/13/1/55

21. European Committee on Antimicrobial Susceptibility Testing. Clinical Breakpoint Tables - bacteria; Version 9.0 2019; http://www.eucast.org

22. Monecke, S., Gavier-Widen, D., Mattsson, R., et al. Detection of mecC-Positive Staphylococcus aureus (CC130-MRSA-XI) in Diseased European Hedgehogs (Erinaceus europaeus) in Sweden. PLOS One. 2013; 8 (6)|: e66166

23. Dagi, H. T., Findik, D., Deirel, G., et al. Detection of Methicillin Resistance and Various Virulence Factors in Staphylococcus aureus Strains Isolated from Nasal Carriers. Balk Med J. 2015; 32: 171-175. DOI:10.5152/balkanmedj.2015.150186

24. Deodhar, D., Varghese, G., Balaji, V., et al. Prevalence of Toxin Genes among the Clinical Isolates of Staphylococcus aureus and its Clinical Impact. J Glob Infect Dis. 2015; 7 (3): 97-102. DOI:10. 4103/0974-777X.162234

25. Abbasi, M., Salehi, M. B., Bahador, N., et al. Antibiotic Resistance Patterns and Virulence Determinants of Different SCCmec and Pulsotypes of Staphylococcus Aureus Isolated from a Major Hospital in Ilam, Iran. Open Microbiol J. 2017; 11: 211-223. DOI: 10.2174/1874285801711010211

26. Sabouni, F., Mahmoudi, S., Bahador, A., et. al. Virulence Factors of Staphylococcus aureus Isolates in an Iranian Referral Children's Hospital. Osong Public Health and Research Perspectives. 2014; 5 (2): 96 - 100. 96e100 http://dx.doi.org/10.1016 Lj.phrp.2014.03.002

27. Nwaogaraku, C. N., Smith, S. I., and Badaki, J. A. Non detection of mecA gene in methicillin resistant Staphylococcus aureus isolates from pigs. Afr J Clin Exper Microbiol. 2019; 20 (2): 159 - 163

28. Aman, M. J., and Adhikari, R. P. Staphylococcal Bicomponent Pore-Forming Toxins: Targets for Prophylaxis and Immunotherapy. Toxins. 2014; 6: 950-972.DOI: 10.3390/toxins6030950

29. Shukla, S. K., Karow, M. E., Brady, J. M., et al. 
Virulence genes and genotypic associations in nasal carriage, community-associated methicillinsusceptible and methicillin-resistant USA400 Staphylococcus aureus isolates. J Clin Microbiol. 2010; 48 (10): 3582 - 3592. DOI: 10.1128 /JCM.00657-10

30. Madani, A., Garakani, K., and Mofrad, M. R. K. Molecular mechanics of Staphylococcus aureus adhesin, CNA, and the inhibition of bacterial adhesion by stretching collagen. PLOS One: 2017: https://doi.org/10.1371/journal.pone.0179601

31. Sauer, P., Sıla, J., Stosová, T., et al. Prevalence of genes encoding extracellular virulence factors among methicillin-resistant Staphylococcus aureus isolates from the University Hospital, Olomouc, Czech Republic. J Med Microbiol. 2008; 57: 403-410. DOI: $10.1099 / j m m .0 .47413-0$

32. Jarraud, S., Peyrat, M. A., Lim, A., et al., A Highly Prevalent Operon of Enterotoxin Gene, Forms a Putative Nursery of Superantigens in Staphylococcus aureus. J Immunol. 2001; 166: 669-677; DOI: 10.4049/jimmunol.166.1.669.
33. Peck, K. R., Baek, J. Y., Song, J. H., et al. Comparison of genotypes and enterotoxin genes between Staphylococcus aureus isolates from blood and nasal colonizers in a Korean hospital. J Korean Med Sci. 2009; 24 (4): 585-591. DOI: 10.3346 /jkms.2009.24.4.585

34. Wang, L. X., Hu, Z. D., Hu, Y. M., et al. Molecular analysis and frequency of Staphylococcus aureus virulence genes isolated from bloodstream infections in a teaching hospital in Tianjin, China. Genet Mol Res. 2013; 12 (1): 646. DOI: 10.4238 /2013.March.11.12

35. Mehtrotra, M., Wang, G., and Johnson, W. M. Multiplex PCR for Detection of Genes for Staphylococcus aureus Enterotoxins, Exfoliative Toxins, Toxic Shock Syndrome Toxin 1, and Methicillin Resistance. J Clin Microbiol. 2000; 38:1032-1035; PMC86330 